Article

\title{
An Exploratory Study of Swedish Charities to Develop a Model for the Reuse-Based Clothing Value Chain
}

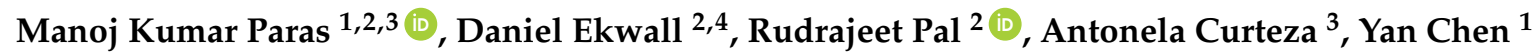 \\ and Lichuan Wang ${ }^{1, *}$ \\ 1 College of Textile and Clothing Engineering, Soochow University, Suzhou 215006 China; \\ manoj.kr.paras@gmail.com (M.K.P.); yanchen@suda.edu.cn (Y.C.) \\ 2 Faculty of Textiles, Engineering and Business, University of Borås, Allégatan 1, 50190 Borås, Sweden; \\ daniel.ekwall@hb.se (D.E.); rudrajeet.pal@hb.se (R.P.) \\ 3 Faculty of Textile, Leather and Industrial Management, "Gheorghe Asachi” Technical University of Iași, \\ 700050 Iași, Romania; acurteza@gmail.comA.C.) \\ 4 Supply Chain Management and Social Responsibility, Hanken School of Economics, Arkadiankatu 22, \\ 00100 Helsinki, Finland \\ * Correspondence: lcwang@suda.edu.cn; Tel.: +86-188-9658-8991
}

Received: 8 March 2018; Accepted: 11 April 2018; Published: 13 April 2018

\begin{abstract}
The present paper aims to explore the current clothes reuse business in order to develop a charity-driven model for the reuse-based clothing value chain. An exploratory study was carried out in Sweden to understand the business flow of clothes reuse. This study builds on the insights gained from the multiple charities involved in the reuse-based clothing value chain. Semi-structured interviews along with direct and participatory observation were used for data collection. In the current study of Swedish charities, the founders and senior managers of the organizations were interviewed. This paper provides several insights in the form of propositions and a model related to different drivers of the reuse-based clothing value chain. In this model, business factors (system, legislation, and awareness), product factors (design, quality, and price), and consumer attitude as donor/buyer are found to be key drivers. Product design, quality, and price depend upon clothes brand, construction, and material, which are collectively important for the sale of used products. In the future, researchers are encouraged to test the present set of propositions and the proposed model across different cultural settings. The model can serve as a framework for practitioners and will be helpful for designing business strategies based on the different factors identified in this study.
\end{abstract}

Keywords: reverse value chain; apparel supply chain; clothes reuse; closed loop; charity driven

\section{Introduction}

In today's dynamic scenario, the unidirectional value chain is generally restructured as a bi-directional chain. In a bidirectional value chain, the forward direction is utilized to convert raw material into a product, while the reverse side is used to recover value from old or discarded products. A reverse value chain comprises different activities, like reuse, repair, redesign, refurbishing, remanufacturing, and recycling. In order to gain competitive advantage, firms have adopted the concept of circular or reverse logistics (RL) [1,2]. Other reasons that can be attributed to this shift may include scarce natural resources, population growth, and degradation of the environment [3]. Some government and nongovernment organizations are focusing on the efficient use of resources and are promoting the concept of circular economy. The government organizations are framing different legislations and designing frameworks to recover discarded products. On the other hand, 
the nongovernment organisations are constantly working to spread awareness about environmental protection among consumers [4].

A substantial amount of effort has been done related to the recovery of plastics, electronics, paper, and others. However, studies related to textile and clothing are limited [5]. The textile and clothing products constitute a significant percentage of daily consumption. Consumers prefer to donate clothing for reuse rather than to dispose of them into the garbage, but convenience dominates their behaviour [6]. In this situation, prompting reuse can avoid environmental hazards incineration and landfilling [7]. The extensive use of synthetic fibres in clothes worsens the situation because these fibres are not decomposed easily. Incineration results in an increase in carbon dioxide and other poisonous gas emissions in the atmosphere, causing harm to the living organisms. Therefore, the importance of recovering existing products through RL is the need of the hour [8]. The efficient management of various RL activities has always been a major concern because of the insufficient attention paid by different stakeholders [9]. Hence, it is important to understand various factors affecting RL. The general perception is that all these activities require a huge initial investment and maintenance cost [10]. In several places, the high-cost assumption is made without considering the value of the recovered resources. Therefore, a proper analysis and measurement are required to design efficient value chains to recover value from discarded products. Thus, it is imperative to apprehend the processes and factors influencing RL [11]. The present study is an attempt to understand the clothes reuse process by finding answers to the below research question:

\section{Research Question: What Are the Main Factors Affecting a Reused-Based Clothing Value Chain?}

To answer this research question, an extensive review of the literature was conducted to figure out important factors affecting RL activities. Building on the important factors identified from the literature, an exploratory research was carried out to understand the functioning of Swedish charity organizations. The study ends with a model, set of propositions, implications, and future scope of the work.

\section{Reuse-Based Clothing Value Chain}

The clothing value chain is relatively complex as compared to the value chains in other industries. This is mainly due to the number of members involved in the execution of different activities [12]. The complexity of RL of clothing is even higher in comparison to other industries [13]. The extant review revealed that it is difficult to recover unused value through reverse value chains, particularly in the case of clothing. It is considered easier to track description and information of the product in the forward supply chain than in a reverse value chain, specifically in collection and sorting activities [14]. Few attempts have been made to study and standardize the reverse value chain in various contexts. A recent study provided insights related to the aftermarket of clothes [15]. The study was an effort to map different practices and provide an understanding of the whole process starting from the collection to the sale of the product in the second-hand market. Further, the author proposed different value addition activities to increase the life of the product, forming an efficient closed-loop value chain.

'Reuse' can be considered as one of the most sustainable ways to close the loop of the value chain. The concept deals with the collection of old products/garments that are free from major defects. The products can be reused directly, requiring only a little extra processing such as washing and finishing [16]. Morley et al. [17] defined 'reuse' as the process of restoring basic functionality. The used clothes can be categorized into market-based formal trade and informal/private exchange. The informal reuse, such as receiving hand-me downs and swapping between friends and families, is relatively larger in volume, especially for children's clothing, than second-hand purchase in Nordic countries [18]. Circulation of maternity wear among friends and relatives is very common among women, and this is one of the oldest ways to sort and circulate clothes from the wardrobe on the basis of its request [19]. The market-based formal trade for local reuse happens through reselling in second-hand shops, reselling on the internet platform, or exchanging at clothing libraries [20]. 
The clothes can also be exported for reuse in case they are not suitable for reuse in local markets [21]. In a survey conducted in Sweden, it was highlighted that out of 100 collected clothes, 60 clothes go for reuse, 30 are recycled, and the remaining 10 go to incineration or landfilling [22]. Consequently, several new business models have emerged for the formal and informal reuse of clothes, such as renting, swapping, internet, and software-based applications [23].There is a huge amount of energy saving in the reuse process. The energy consumed in the collection, sorting, baling, and distribution process is only $2.6 \%$ (for cotton) and $1.8 \%$ (for polyester) as compared to the energy necessary to manufacture clothes from raw materials [24].

\section{Factors Affecting the Reused-Based Clothing Value Chain}

There are several factors that affect clothes reuse in the reverse value chain. Paras et al. [25] have identified the six factors that influence the reuse of clothes. These are: system, design, price, information, legislation, and consumer (as buyer and donor) attitude. This research is an effort to build on the conceptual framework proposed by Paras et al. [25] as shown in Figure 1.

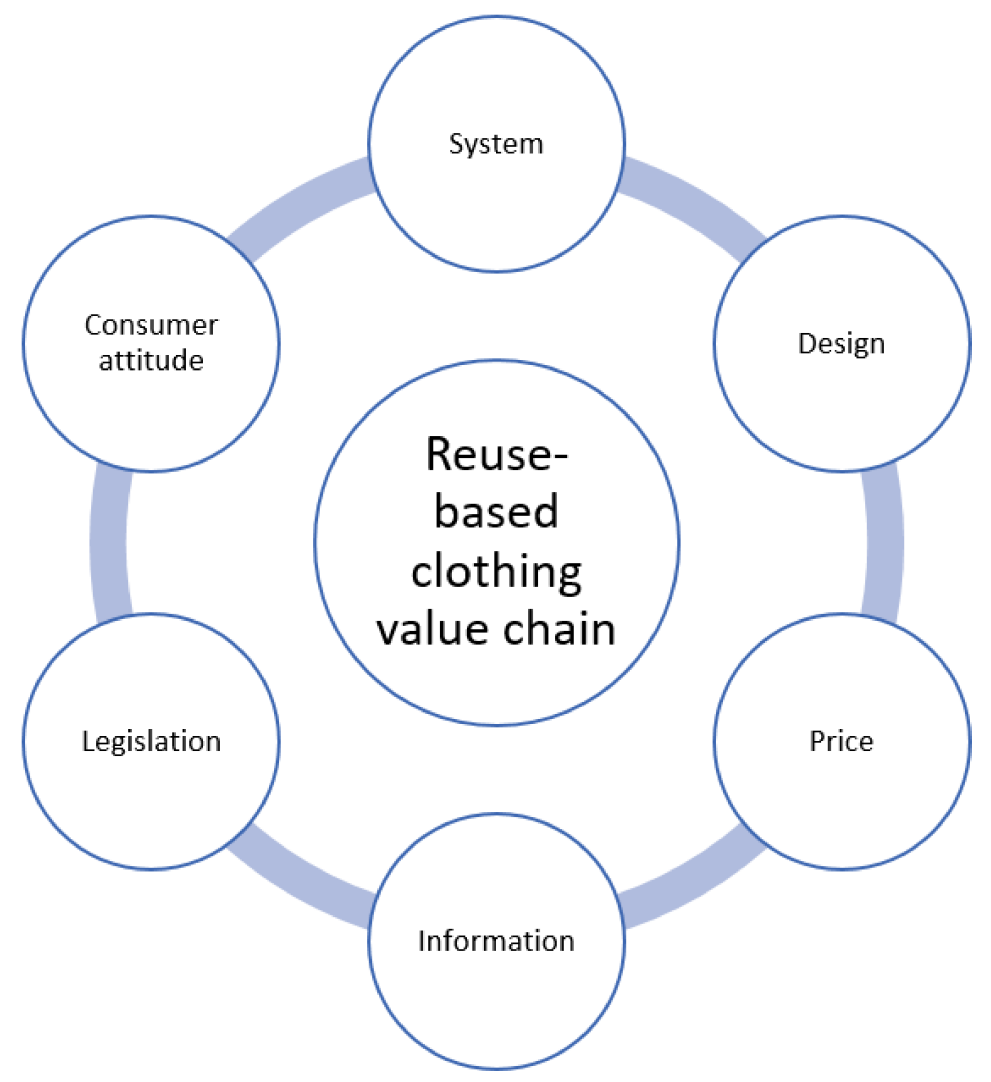

Figure 1. Reuse-based clothing value chain adapted from [25].

\subsection{System}

The reuse-based clothing business is considered much more complex than other value chains [26]. With the increase in global production, distribution, and consumption, the complexity of the reuse-based clothing industry has increased immensely in the recent years [27]. Factors such as quality, quantity, composition, and style, make clothing business heterogeneous and multifaceted [28]. Most of the second-hand clothing businesses are run by charity organisations. Although these charity organisations are well structured for collecting used clothes, they lack in technical and managerial skills necessary to manage other aspects of the business [29,30]. Parsons [31] raised a concern related to the future of 'charity' as an organization. However, the charity organization has a good image in the society, 
and charities also sell products at lower prices, thus they offer a huge opportunity. Hence, there should be a collaborative model for doing business. The prominent players in the clothes and textile sector can also enter the second-hand market [32]. In a case study of apparel aftermarket in India, it was found that fragmentation is the main reason for inefficiency. The efficiency of second-hand clothing business can be further improved by developing joint ventures between charities and retailers [15].

Textile, fabric, and product knowledge are required to distinguish valuable products from trash [33]. Various techniques of production management can be utilised to convert used clothes into saleable products [15]. In the Textile4Textile project, an automatic machine was developed to sort clothes based on their composition, colour, and type. This was found to be one of the useful interventions to avoid manual error-prone RL activities such as sorting [34].

\subsection{Design}

The design-conscious consumers visit second-hand stores in search of vintage or unique products [35]. In a survey conducted on USA consumers, it was found that consumers have interest towards old and vintage clothing because of its unique design [36]. In the current situation, there is a trend among youngsters to quickly change their clothes, whereas consumer groups like elderly people wear clothing for a longer time. As a result, youngsters do frequent shopping [37]. Teherefore, product durability is not a major concern for either the consumer or the manufacturer [38]. The RL's biggest problem is the product's short life cycle. In particular, clothing products are sold by fast fashion companies having shorter lives [32]. For example, leading clothing brands, such as H\&M, $M \& S$, and Zara offer a new, low-priced product line every two to three weeks [37]. A product's durability has a direct impact on the redesign. If a product is durable, it can undergo the process of repair/redesign [39]. Morana and Seuring [40] suggested that product lifetime and margin are the major factors that affect redesign. The scope of the second-hand clothes will only increase if the value of the old product can be enhanced by improving the garments using design elements like embroidery, prints, and dyes on clothes. In several occasions, the consumer may want a new look for his/her old clothes. This can also be done by redesigning and, hence, extending the life of old clothes for self-use [41]. It has been found that product, process, and supply chain design should work concurrently and independently to achieve a sustainable design [39].

\subsection{Price}

Prior to the mass production of clothes, old or second-hand clothes were used by family members who could not afford new ones [42]. The business of second-hand goods is rooted in scarcity, where clothes were exchanged. Later, informal exchange took the shape of formal trade and, gradually, it reshaped into a large-scale commercial form of business [43]. The price of second-hand products is another factor that is critical to the success of RLs because the saleability of a second-hand product depends largely upon its price compared to that of an equivalent new product [44-46]. Vorasayan and Ryan [47] noted that even a small change in the cost of refurbishing affects the price difference (between new and used clothes); therefore, one needs to be extra conscious of the costs incurred in the collection, sorting, and remanufacturing processes [48]. In this context, several optimal pricing techniques, e.g., the use of fuzzy logic to determine optimal pricing for the remanufacturing, wholesaling, and retailing of used products, have been examined by Zhao et al. [49] to determine how manufacturers and retailers make decisions. Manufacturers can decide to use new or reusable material on the basis of economic advantage. Retailers can measure the rate and economic advantage of selling remanufactured products. Profit realisation through optimal pricing can be considered as one of the major factors in determining the success of the RL. The optimal price of a used product is based upon the cost incurred in product acquisition, testing, sorting, grading, reconditioning, and remarketing [40]. However, firms need to fix the price of second-hand products in such a way that customers are willing to pay for them [50]. 


\subsection{Information}

Companies such as H\&M offer discount coupons to encourage consumers to return used clothes to their stores [32]. Product returns in the presence of an offer are much better than a third-party collection [51]. One common problem in RL is the unavailability of information across all partners in the reverse supply chain [52]. Through proper communication between exporters and importers, quality problems involving second-hand clothes can be reduced. The trade in second-hand clothes is subjective in nature because of product and quality variation [53]. The information system can play a crucial role in sorting clothes because the clothes sorting process is very hectic and complex [45]. A study of consumers' disposable behaviour showed that consumers are unaware about the impact of textile waste on the environment [54]. There is a need to increase consumer awareness with the help of a good information system that addresses sustainable practices [54].

\subsection{Legislation}

The government promotes reuse through tax exemptions and other monetary benefits. For example, the Swedish tax agency has recently created an exemption from the value-added tax for the sale of second-hand goods. It has been recommended that the sale of second-hand donated goods should be done by charity or religious organisations to finance non-profit projects [25]. A study [55] has also emphasised the role of legislation to promote the sale and use of remanufactured products. Ma et al. [56] have highlighted the importance of government subsidies for the RL. Natural resources are limited and must be saved for the future. Therefore, there is a need for government rules and interventions to promote the conservation of resources. To illustrate this point, Sweden's government recently reduced the value-added tax from $25 \%$ to $12 \%$ for the repair of goods, including clothes. France's government imposes penalties for intentionally producing goods with a short life. Spain and Germany have also planned to implement similar laws in the coming years [25]. The government can promote the local collection and reuse of second-hand clothes. To strengthen reuse practices, all members of the society need to play a significant role [38]. It has been suggested to extend producers' responsibility to make the environment more friendly, sustainable, and a better place to live [57].

\subsection{Consumer Attitude as a Donor and Buyer}

An environment-conscious consumer tends to purchase environment friendly products and might have a positive attitude towards second-hand garments [58]. In a survey conducted in Chile and Austria, it has been found that consumers' environment consciousness acts as a direct driver of donation to charities. In addition, several demographic factors such as consumers' age and gender also affect consumers' behaviour significantly [59]. Nowadays, consumers exhibit high alertness related to new clothes purchase and their impact on the environment. This is demonstrated, firstly, by purchasing clothes in a limited way and according to the requirement; secondly, by purchasing environment-friendly or organic products; thirdly, by purchasing from second-hand stores [60]. The consumers' positive attitude towards sustainability can bring a huge change in the society because an environmentally conscious consumer tends to purchase more environment-friendly clothes and also tries to participate in various initiatives to save the planet [61].

A study evaluating the RL has found that environmentally conscious people have a positive attitude towards conserving resources for future generations [3]. Purchase decisions about second-hand products are directly influenced by consumer attitudes. A study done in China by Wang et al. [62] noted that environmentally conscious consumers tend to purchase recycled or second-hand products. In addition, they exhibit other sustainable behaviours, such as wearing new clothes for longer and trying to repair damaged clothes [63]. Consumers' purchase decisions related to clothing are also influenced by peer pressure, job requirements, self-identity, and the influence of retailers [58]. For example, Mothercare in the UK has launched a campaign called GiftABundle in collaboration with 
the environmental charity 'Hubbub'. The campaign GiftABundle addresses the issue of outgrown baby clothes by providing a way for parents to pass on outgrown, good-quality babywear to families in need [64].

\section{Methodology}

The clothing value chain comprises multiple stakeholders and is influenced by different actors that give multiple perspectives to the topic. The theory building exercise went through explication, explanation, and exploration stages. At the explication stage, an attempt has been made to understand the phenomena of clothes reuse. The relationship among various factors has been understood through the analytical move of explanation [65]. It is important to build a new theory rather than verifying or falsifying the existing ones, because reality changes frequently. The logical interference of abduction has been used to achieve theoretical saturation [66]. Czarniawska [67] described an abductive approach that gives the opportunity to explore the existing practice of clothes reuse business and also provides a chance to re-investigate the theoretical knowledge after data collection.

\subsection{Case Design}

This study opted for multiple case observations. This allowed the development of a rich knowledge by analysing various practices in the clothes reuse business. Multiple cases provided robustness to study [68]. This study followed a purposive sampling technique which is dominantly used in qualitative research [69]. In order to identify the potential organizations, the researcher thoroughly searched information on secondary resources. Nearly 20 organizations located in western Sweden were contacted by email and telephone. The first contact was established with a customer care representative or logistics manager. In some cases, the initial contact was established with the director or the chief executive officer. Some organizations were not qualified or selected on the basis of their retail/supply chain operations or interest in research. The focus of the current study was to understand the clothes reuse practices from the supply chain perspective. Hence, the organizations involved only in retail and sales were excluded. Finally, five case studies were selected. These case studies comprised five major organizations. These were referred to as A, B, C, D, and E to maintain confidentiality. The first two firms (A and B) are individual charity organisations, whereas $C$ and $D$ are organisations affiliated with international charity organisations. The fifth organisation, $\mathrm{E}$, is run by the local Municipal Corporation.

\subsection{Data Collection and Analysis}

Interview is a popular and frequently used technique in social science for information collection. This gives a prospect to capture dialogue and produce a narrative of the observation [70]. During the interviews, focus was given on interrogating the fact and reality of the organization. Even though the mutual exchange of ideas is good in knowledge generation, due respect should be given to the interviewees to gain knowledge, as this provides the researcher a chance to ask relevant questions [71]. Most of the interviews were intensive in nature and extended for more than one hour. It has been observed that longer interviews give a better opportunity to capture information [72]. Each interview started from understanding organisations' views and practice of the business of clothes reuse. This brought both parties, i.e., interviewee and interviewer on a common platform. Silverman [73] suggested the interviewer should also consider the importance of observing the organization settings. Therefore, the behaviours and surroundings of the interviewee was carefully observed and recorded for the generation of knowledge. There are different ways of observation to capture information. The technique of direct observation was adopted for this study. Direct observation was further divided into participant observation and non-participant observation. The participant or self-observation approach provided better judgment of the organisations. The researcher involved worked as volunteer in one of the organisations to gain meaningful insights [74]. However, because of the constraint of time and permission, non-participant observation, such as shadowing and stationary observation, have been 
performed in the majority of studies. It is important to study the way people work in organizations. Photographs and videos have also been taken to support the observations made [75]. Diary and other field notes have been taken to complement the recorded interviews and observations [76]. In this study, field notes were accurately written for the non-recorded part of the interview, so that information could be completed at the time of transcription and analysis. The details of the observations and interviews are depicted below in Table 1.

Table 1. Details of interviews and observations.

\begin{tabular}{|c|c|c|c|c|c|}
\hline \multirow{2}{*}{ Organization } & \multirow{2}{*}{$\begin{array}{l}\text { Number } \\
\text { of Visits }\end{array}$} & \multirow{2}{*}{ Observations } & \multicolumn{2}{|c|}{ Interviews (Face to Face) } & \multirow{2}{*}{ Documents } \\
\hline & & & Type & Duration & \\
\hline \multirow{3}{*}{ A } & \multirow{3}{*}{07} & $\begin{array}{l}\text { Participatory observation as a } \\
\text { volunteer in the textile leftover } \\
\text { section. }\end{array}$ & \multirow{3}{*}{ Indivi4dual } & \multirow{3}{*}{$\begin{array}{l}\text { Founder }(>1 \mathrm{~h}) \text { and } \\
\text { chief operation } \\
\text { manager }(>1 \mathrm{~h})\end{array}$} & \multirow{3}{*}{$\begin{array}{l}\text { Grading category list, } \\
\text { advertisement pamphlet, } \\
\text { feedback forms, and } \\
\text { accounting sheets }\end{array}$} \\
\hline & & $\begin{array}{l}\text { Observed process of sorting and } \\
\text { reprocessing. }\end{array}$ & & & \\
\hline & & $\begin{array}{l}\text { Multiple visits to various sections of } \\
\text { the organization. }\end{array}$ & & & \\
\hline B & 01 & $\begin{array}{l}\text { Visit to shop, collection (unloading), } \\
\text { sorting and reprocessing sections. }\end{array}$ & Individual & Founder (>1 h) & Accounting sheets. \\
\hline C & 03 & $\begin{array}{l}\text { Visit to shop, sorting and } \\
\text { reprocessing sections. }\end{array}$ & Individual & Founder $(>1 \mathrm{~h})$ & $\begin{array}{l}\text { Video files, organisation } \\
\text { brochure, accounting } \\
\text { Sheets }\end{array}$ \\
\hline D & 03 & $\begin{array}{l}\text { Visit to shop, sorting and } \\
\text { reprocessing sections. }\end{array}$ & Individual & Founder (>1 h) & None \\
\hline E & 02 & $\begin{array}{l}\text { Visit to shop, collection (unloading), } \\
\text { sorting and reprocessing sections. }\end{array}$ & Group & $\begin{array}{l}\text { Four managers } \\
(>1 \mathrm{~h})\end{array}$ & Sales sheets \\
\hline
\end{tabular}

All kind of field materials were collected, transcribed, and interpreted. The collected material was kept under constant comparative analysis till theoretical saturation [66]. A narrative analysis was used for the classification and categorisation of the collected material under headings such as system, design, price, and others. Various codes and emerging themes, such as collection and value creation methods, were generated on the basis of this thematic analysis. Discourse and conversation analysis were adopted for the empirical examination of interviews and other field material such as documents and images. Individually, each interview was analysed by conversation analysis. Discourse analysis was employed to analyse various conversations, which took place over six months (from September 2015 to February 2016) in different organisations [70]. Visual analysis was carried out to compare processes (collection and sorting) in different companies. Later, a close analysis was done of the text reporting information collected from the field. The traditional approach of structural analysis was used to understand the relationship between different narratives [77]. Eventually, this provided a clear understanding of the structure and function of intricate narratives. Greimas et al. [78] introduced the concept of actant for human (donors, collectors, sorter, and buyers) and nonhuman (clothes) objects. The machine has taken a central place in structuralism. This technique was harnessed to understand the effect of the actor on the actant throughout the RL process of clothes.

\section{Findings}

This section will provide practical instances to enhance our understanding related to RL. The qualitative insights gained helped in analysing the status quo of practice.

\subsection{Current Practice in the Selected Organizations}

Table 2 summarizes the current practices involved in the business of second-hand clothing. The interviews revealed that all five companies had different ways and means to do collection, sorting, and sales. Organization A and B were working individually. These organizations performed every task independently, while C, D, and E took help from their affiliated organizations. Three kinds of ownership exist among the existing charity organisations. First, there are privately owned charity organizations which work under their own brand name. Second, there are organisations which are 
owned by an individual but work under the brand name of international charity organisations. Third, there are organisations that are owned by the local government (municipality). The findings also suggested that charity organizations run by an individual are keen on donating used clothes to people in need. These organizations are not interested in donating money to foreign organization because they believe that money can be easily misused. Organization A aims to transport second-hand clothes to Finland and Ukraine. The organization feels it difficult to ship to Africa, hence, second-hand clothes were sold to a dealer. The money earned from the sale of clothes is used for charity work. Charity organization B uses its own trucks to transport used clothes to Latvia. The goods are distributed among a few social organizations in Latvia. These goods are further re-distributed among the local people in need. Our findings also showed that Organization C and D work under the umbrella of an international charity organization. They use to send the earned profit to the Swedish head office of the international charity organization. Later on, money is used in various development projects in developing countries. However, organization $\mathrm{C}$ and $\mathrm{D}$ are also responsible for moving unsold and sorted material (not suitable for sale in store) to the central location. At the central location, the clothes are resorted and graded, and the usable clothes are exported, while the damaged clothes are disposed to an energy station for incineration. Organization $E$ is unique in nature because it is run by the local government/municipality. The primary goal of this organization is to provide a workplace for disabled persons. However, this organisation performs sorting activities for a multinational charity organization located in a nearby city. Organization E is being paid one Swedish Kronor (SEK) for every two kilograms of sorted clothes. Moreover, all profits made on the sale of clothes also go to the same multinational charity organization. On average, the organization gets $800-1000 \mathrm{~kg}$ of clothes for sorting and has very good facilities for repairing and washing. Washing facilities are also used to earn a profit by washing the uniforms of people working in a cafeteria run by the municipality.

Table 2. Current practice of clothes reuse in the selected organizations.

\begin{tabular}{|c|c|c|c|c|c|}
\hline Details & Organization A & Organization B & Organization C & Organization D & Organization E \\
\hline $\begin{array}{l}\text { Collection } \\
\text { methods }\end{array}$ & $\begin{array}{l}\text { 1. On-call service for } \\
\text { bulk donation. } \\
\text { 2. Direct handover }\end{array}$ & $\begin{array}{l}\text { 1. On-call service } \\
\text { for bulk donation. } \\
\text { 2. Direct handover } \\
\text { 3. Collection Bins }\end{array}$ & 1. Direct handover & $\begin{array}{l}\text { 1. Direct handover } \\
\text { 2. On-call service }\end{array}$ & $\begin{array}{l}\text { 1. Collection Bins } \\
\text { 2. Direct handover }\end{array}$ \\
\hline $\begin{array}{l}\text { Type of } \\
\text { donation }\end{array}$ & $\begin{array}{l}\text { 1. Personnel and } \\
\text { household } \\
\text { 2. Industrial leftover } \\
\text { fabrics and trims }\end{array}$ & $\begin{array}{l}\text { 1. Personnel and } \\
\text { household } \\
\text { 2. Industrial } \\
\text { leftover fabrics } \\
\text { and trims }\end{array}$ & $\begin{array}{l}\text { 1. Personnel and } \\
\text { household }\end{array}$ & $\begin{array}{l}\text { 1. Personnel and } \\
\text { household } \\
\text { 2. Unsold items } \\
\text { form retail \& } \\
\text { online stores }\end{array}$ & 1. Personnel and household \\
\hline $\begin{array}{c}\text { Availability } \\
\text { of } \\
\text { transportatio } \\
\mathbf{n}\end{array}$ & Inbound & $\begin{array}{l}\text { Inbound/Outboun } \\
\mathrm{d}\end{array}$ & No & Personnel car used & Sister organization \\
\hline $\begin{array}{c}\text { Sorting } \\
\text { facilities }\end{array}$ & \multicolumn{5}{|l|}{ Manual Sorting } \\
\hline $\begin{array}{l}\text { Sorting } \\
\text { criteria }\end{array}$ & $\begin{array}{l}\text { Perfect- Sweden in } \\
\text { different categories, } \\
\text { Winter-Romania, } \\
\text { Winter (good } \\
\text { quality)-Finland. } \\
\text { All Others- Africa (In } \\
\text { different Categories), } \\
\text { Defected-Garbage. }\end{array}$ & $\begin{array}{l}\text { Good Quality- } \\
\text { Sweden, } \\
\text { All Other- Latvia } \\
\text { in different } \\
\text { Categories }\end{array}$ & \multicolumn{2}{|c|}{$\begin{array}{l}\text { Good Quality- Sweden/ self-store, } \\
\text { Rest Other- Central Warehouse, } \\
\text { Defected- Recycling Station. }\end{array}$} & $\begin{array}{l}\text { Normal Quality- Sales in } \\
\text { store, } \\
\text { Good quality- Sorted for } \\
\text { collector store, } \\
\text { Summer Clothes- Africa, } \\
\text { Others- Eastern Europe, } \\
\text { Dirty/Washable- for } \\
\text { cleaning, } \\
\text { Specific Order- for Church } \\
\text { Defected- Recycling }\end{array}$ \\
\hline $\begin{array}{l}\text { Reprocessing } \\
\text { facilities }\end{array}$ & $\begin{array}{l}\text { Ironing, Minor by } \\
\text { hand. }\end{array}$ & $\begin{array}{l}\text { Ironing, } \\
\text { Minor by hand, } \\
\text { Cleaning facilities } \\
\text { for rare use. }\end{array}$ & $\begin{array}{l}\text { Ironing, } \\
\text { Minor by hand, } \\
\text { Cleaning facilities } \\
\text { for rarer use. }\end{array}$ & $\begin{array}{l}\text { Ironing, } \\
\text { Minor by hand. }\end{array}$ & $\begin{array}{l}\text { Ironing, } \\
\text { Minor by Machines. } \\
\text { Full cleaning facilities/order } \\
\text { for cleanings are also taken. }\end{array}$ \\
\hline Sale & $\begin{array}{l}\text { A limited amount of } \\
\text { in-house sale } \\
\text { Majority sale to } \\
\text { Africa }\end{array}$ & $\begin{array}{l}\text { A limited amount } \\
\text { of in-house sale } \\
\text { Majority donation } \\
\text { to Latvia. }\end{array}$ & $\begin{array}{l}\text { Almost } 40 \% \text { are } \\
\text { sold in house } \\
\text { the remaining is } \\
\text { sent to a central } \\
\text { warehouse. }\end{array}$ & $\begin{array}{l}\text { Almost } 40 \% \text { are } \\
\text { sold in house } \\
\text { the remaining is } \\
\text { sent to a central } \\
\text { warehouse. }\end{array}$ & $\begin{array}{l}\text { A limited amount of In- } \\
\text { house sale } \\
\text { The majority are taken back } \\
\text { by the collection company. } \\
\text { Collector pays } 1 \text { SEK for } \\
\text { every } 2 \mathrm{~kg} \text { of sorted clothes. }\end{array}$ \\
\hline
\end{tabular}




\subsection{Cross-Case Synthesis}

There is not abundant information available to appreciate the existence of proper channels or avenues to discard and reuse the clothes. To understand the discourse of textile and clothes recovery, the interviewer tried to shed light on a few factors for better understanding. The findings below were derived from a cross-case analysis of the selected five cases and grouped into six categories according to factors identified in the literature. More precisely, this study investigated different factors influencing the RL of clothes reuse.

\subsubsection{System}

The systems were found to be one of the most crucial parameters for the success of second-hand clothing business. Organization A currently functions from two locations in nearby areas. At the main location, they have a shopping area for furniture and leftovers received from the textile industry. Clothes, crockery, electronics, and books are kept at the other location. This leads to loss of sales as the customer is not able to see all the goods available for purchase at one location. Hence, the organization is planning to move to new premises which will have almost double space. According to the founder of organization A:

"The second-hand business is a money generator for us. Hence, it is very much important to have good working conditions for employees/volunteers, and offer the best shopping experience to the customers. The new premises will have a proper storage facility and provide a dust-free working environment"

Besides space, the network plays an important role in the collection as well the distribution of second-hand goods. Organization A founder has been personally involved in the clothing charity for a long time and has a good network in Sweden and abroad. This helps the organisation receive donations from a variety of sources, including hospitals and companies. Further, his overseas contacts strengthen the logistics and distribution of second-hand goods. The organisation collects bulky items such as furniture by using their own vehicles but, often, clothing and other household items are also received. Even though organization B is located in a small place, it has a good amount of collected material. as there is no other organization working in the vicinity. The organisation has its own premises, which help them to save money. Organization B was founded with the aim to help people of Latvia. Organization B has collaborated with social organisations of Latvia for the distribution of second-hand items. The availability of its own trucks and vans further facilitates the collection and transportation of goods to Latvia.

Organization C has only a $300 \mathrm{~m}^{2}$ area, out of which an area of hardly $30-40 \mathrm{~m}^{2}$ is allocated for storage and sorting activities. The chairman of the organization $C$ would like to have a larger space and easier accessibility to its own logistics. However, at the same time, he has asserted the organisation's inability to afford this. Further, the organization does not transport goods to developing countries, since the goods are sold locally in Sweden. However, the organisation has a good layout design of the retail floor. The chairman of organization $C$ has highlighted the importance of plan and processes in doing charity-based social business. As this organization works under the leadership of an international charity, it is able to get proper guidance in starting and doing day-to-day business. For every volunteer who joins, training is given to highlight the mission and vision of the organization. Regular training provided by the head office also helps improve the skills of the volunteers. However, training does not focus on the processes of collection, sorting, repair. The need for technical training was shown by organization $C$. The association of organization $D$ with an international charity and its location in the city centre are its biggest advantages. Many online retailers and offline retail stores have been approached for donation of unsold items. Branded new items have helped in earning good revenues.

As $\mathrm{E}$ is a local government organization, this is the biggest advantage to it. The association with a multinational charity organization leader in second-hand retailing provides an extra ease in doing business. Collection bins placed by a charity organization at different locations in the city and 
assistance provided by the sister organization in bringing in the collected material weekly, ensure sufficient inputs for sorting. Disabled people provide assistance in doing most of the work, i.e., sorting, washing, repairing, and sales. Employees are responsible for decision-making and for planning the day-to-day work for all volunteers and employees.

\subsubsection{Design}

The business of second-hand clothing in organization B was started on the basis of the concept of vintage. Gradually, this business has moved from high fashion to basic garments. The styles and the construction of fabric and clothes play a major role in purchase decisions. In the interview, it was also acknowledged that most of the customers visit the second-hand store in search of vintage clothing. According to the founder of organization B:

"Design of second-hand clothes certainly matters, as customers are visiting stores from different cities in search of vintage".

In bigger cities, there are multiple second-hand stores; still, it is hard to find unique designs in those stores. Hence, the organisation visits a second-hand shop in a small town in search of vintage. This was also highlighted by the chairman of organisation C. As per him, young women are keen to wear old styles, while teenagers look for some stylish tops. So, each customer targets different types of products. However, the manager of organization E expressed a different opinion on it:

"Design, brand, and price for any product matter together. Customers first look for good brand/design, then have a look on price. Beside this, often ladies are coming in search of long black dresses which are rarely available in our shop".

According to organization E, design has a vital role in decision-making. However, this is not the only deciding factor; quality and price are also crucial factors. Therefore, it is difficult to determine which factors have the highest influence on the purchase decision. Although design plays a crucial role, the influence of brand and price cannot be ignored. There is a high demand for better design and quality products in domestic as well as in international markets. The chief operating officer of organization A also highlighted the importance of design as follow:

"Yes, these days, many companies are selling goods to Africa. Hence, good quality and design clothes are in high demand. Especially, summer clothes are in demand in Africa because of the hot weather".

The product of a famous clothes brand is considered to be diamond and is always handpicked by local buyers and international traders. The above-mentioned exploratory evidence highlights the importance of design in the selection of second-hand clothes.

\subsubsection{Price}

Price is one of the key factors which influence any trade. This becomes even a more important determinant in the used clothing business. A large number of consumers of second-hand clothes cannot purchase new clothes. Organization E mentioned that refugees and people from Eastern Europe visit their store in search of cheaper products. Customers even buy products in bulk and send them to their home country for friends and relatives. Individual charity organizations like A and B have generally low prices for their products, whereas the professionally managed organizations $C, D$, and E have higher prices for their products. According to the founder of organization B:

"Customers are attentive to product prices, and we have competition with other second-hand stores in the region".

This shows that competition exists among different aftermarket stores. They try to set prices as low as possible to increase sales. Because of price differences, customers visit the stores of A and B, even though these are not strategically located in the market. Sometimes, 50\% discounts are offered to 
increase the sales in organization C during Christmas. In organization D and E, it has been observed that price matters a lot to the customers. Sometimes, they even ask for discounts on the current prices. Organization $\mathrm{E}$ are flexible and give little discounts to those who purchase large quantities. If clothes are found to be of better quality, the buyer is willing to pay a higher price. High-fashion or vintage clothes available in second-hand shops are less considered if their quality is inferior. As the chairman of organisation C stated:

"Design, quality, and price of the product matter simultaneously for the customers. The purchase decision is made on the basis of all factors".

The above evidence does not show the importance of price as an independent factor. Price was discussed in relation to quality, brand, and design.

\subsubsection{Information}

Almost all organizations confirmed the importance of information to increase the collection as well as the sale of their goods. Organization A was found to be the most innovative, since it follows most of the available methods to reach out to people. Organization E is less popular among the inhabitants living in nearby areas. The managers of organization $\mathrm{E}$ shared that often customers ask:

"How long have you been here? I have never heard about your store"

This clearly shows the importance of awareness and information about particular second-hand shops or collection centres. Organization A has shown the importance of word-of-mouth publicity which can be done by volunteers and customers. Advertisements are also occasionally run in the local newspaper. In the digital world, it is very much important for an organization to have regularly updated information on websites and social media. The organisations try to do their best to update information in the digital space but are not able to do it completely. The conventional methods of advertisements like posters and signboards are also used. Posters are posted on notice boards in public places, i.e., near the city centre, bus stands, university and other places, while signboards are placed near the store on the main road. A feedback form to fill is given to new customers who visit the shop in organization A. This gives the organisation an idea about how to reach out to people. Table 3 highlights the different ways used by the organisations to bring awareness of their existence to people:

Table 3. Approaches to bring awareness about second-hand clothing.

\begin{tabular}{cl}
\hline Organization & \multicolumn{1}{c}{ Approach to Bring Awareness } \\
\hline A & $\begin{array}{l}\text { Word-of-mouth Publicity, Newspaper Advertisements, Internet, Posters and } \\
\text { Signboards }\end{array}$ \\
\hline B & News Coverage and Promotion by Latvia government \\
\hline C & $\begin{array}{l}\text { Advertisements, Inviting people groups, Social media and International charity } \\
\text { organization websites }\end{array}$ \\
\hline D & $\begin{array}{l}\text { Advertisements, International charity organization websites and Planning to start a } \\
\text { social media webpage and own website }\end{array}$ \\
\hline E & Advertisements. \\
\hline
\end{tabular}

Newspaper coverage is found to be a much more powerful tool to reach people compared to advertisements. Organization B is able to get coverage in the newspaper because it works very closely with government agencies. Currently, the organisation is providing internships to Latvia school students in Sweden, while Swedish students are hosted in Latvia. The association with Latvia government helps the organisation to get coverage in Latvia newspapers. However, organizations $C$ and D found it very difficult to get newspaper coverage, even though they work under the umbrella of an international charity organization. Organization $C$ practices an innovative approach by inviting different groups, i.e., old-age people, school students, and others specific groups. Besides this, an update of their unique and vintage products is posted on social media. Organization E runs 
advertisements once or twice in a year. This is the main reason why its presence is not well known. The above evidence shows the importance of people awareness about used clothing businesses.

\subsubsection{Legislation}

Second-hand clothing businesses are mostly run by charity organizations because there is not much profit which can attract private players. In this situation, it becomes very important for the government to play a key role in supporting their survival. The Swedish government does not directly give benefits to second-hand clothing businesses. Consequently, the imposition of a value added tax on second-hand clothing has raised huge protests. As per the founder of organization A:

"Government decision to withdraw the value added tax for second-hand charity organizations is a great relief for us".

However, the policies of different government agencies can be applied to these social businesses. For instance, organization A gets financial support from the local municipality for employing disabled, alcoholics, and prisoners, while job agencies provide $80 \%$ of the salary to unskilled and untrained persons. Table 4 summarizes the way in which the government legislation helps the different organizations:

Table 4. Benefits of the government legislation.

\begin{tabular}{cl}
\hline Organization & \multicolumn{1}{c}{ Government Legislation Benefits } \\
\hline A & $\begin{array}{l}\text { Incentives for disabled, prisoner, and alcoholic person employment. } \\
\text { Contribution by job agencies for unskilled/training person. }\end{array}$ \\
\hline & $\begin{array}{l}\text { European Union support for starting up. } \\
\text { Municipality incentives for disabled persons. } \\
\text { Contribution by job agencies for unskilled/training person. } \\
\text { National social agencies support for social work. }\end{array}$ \\
\hline C & Financial help from an International Charity organisation. \\
\hline D & Disabled and training/unskilled persons worked in the past. \\
\hline E & Salary to the employees. \\
& Daily allowance to all disabled persons. \\
& All expenses, including rent, by local government. \\
\hline
\end{tabular}

Organization B works closely with the government. They got start-up funding from the European Union. National social agencies also pay for social work. Besides this, this organisation is also able to get support from job agencies and the municipality for the employment of unskilled and disabled persons, respectively. The chairman of organization $C$ worked for an international charity organization for more than 40 years. This helped him to get start-up support from them. Even though no unskilled and disabled people worked for the organization in the past, the organisation has always wanted to offer them work. Organisation D worked with this kind of persons in past but they do not work with them currently.

Organization E gets all kinds of support from the government, as they work under the municipality. Their employees get a salary similar to that of other government organizations. All expenses, including rent, are paid by government agencies. Besides this, all disabled persons who work with organization E get a fixed daily allowance. This clearly shows that an improved social welfare law has a positive impact on the business of second-hand clothing.

\subsubsection{Consumer Attitude as a Donor and Buyer}

The attitude of the consumer is very subjective in nature. It varies from person to person. Usually, rich people are donating dirty and damaged clothes, according to organization D. Organization C has found that, most of the time, good quality clothes are donated. According to the manager of organization E: 
The behaviour of the customers varies, almost $80 \%$ of people come with good quality clothes, while the remaining come with poor quality clothes. Sometimes, even garbage is found in the bins, maybe this is due to a mistake".

Organization B has never found garbage in the collection bins. However, as per the experience of the founder, this kind of practice is generally observed in big cities. The founder of organisation $B$ thinks that because of the countryside location of the organisation, they are able to receive good quality donations. The consumer attitude as a buyer also influences the second-hand clothing business. An environment-conscious consumer is likely to be a potential buyer. At the same time, a consumer with less purchasing power is likely to visit second-hand clothes outlets in search of a cheaper product. There is a third kind of buyer that is called buyer of vintage clothes. This kind wants to look different and would like to wear something from the 1980s or 1990s to look different. The consumer attitude has a significant impact on the second-hand business as well as on the acquisition of discarded products.

\section{Discussion}

The system, price, design, awareness, legislation, and consumer attitude (as a donor and buyer) emerged as prominent factors influencing the RL of clothing. It was observed that most of these factors influence the processes independently or collectively. For instance, the system to perform business is the foundation of any business. Without a well-established business plan, second-hand clothes can neither be sold nor consumed. Thus, there is a need for proper infrastructures to collect, sort, and reprocess old clothes. The business plan consists of arrangements and facilities that affects the RL of clothing. On the basis of our extensive review and empirical findings, it can be derived that product design has an impact on clothes reuse. Discarded or used products are sorted and graded on the basis of their style and construction. Upon segregation, if the products are found to be of vintage nature, then reprocessing requires careful attention. Vintage and branded products are fast-moving items in the second-hand market. The vintage and branded products are considered as 'diamonds' and are quickly picked up by consumers. Price may be considered another important factor which has an overall influence. The cost of each activity ultimately determines the final price of a second-hand product. Beside this, quality is another of the most important factors which decides the saleability of a product at a particular price. Second-hand market information and government legislation tend to have an impact on sales, consumption, and collection. Li et al. [55] discussed the role of government in the promotion of sales and consumption of used products. The awareness of consumers about the second-hand market is also an important dimension. Marketing and advertising along with programmes to increase consumers' awareness may be used to reach more consumers [2]. Guidelines from the government are available for the waste management of many products. Also the end consumers should be well informed about the different ways of disposal which might have a positive impact on the collection process. However, this is also influenced by consumers' attitude. Consumers with a positive attitude towards the environment are favorable to second-hand purchasing and proper disposal of discarded items. Besides this, consumers can also think about redesigning old clothes to increase their usability. Paras and Pal [79] in their study on Nordic countries proposed a reuse-based model for the clothing value chain. In the model, the authors identified the collection, sorting, reprocessing, and disposal stages through which clothes undergo. The present work was undertaken to identify the different factors that determine the movement of clothes from one stage to other. Based on the aforementioned finding and discussion, a model has been proposed to illustrate the influence of different factors on clothes reuse as shown in Figure 2. 


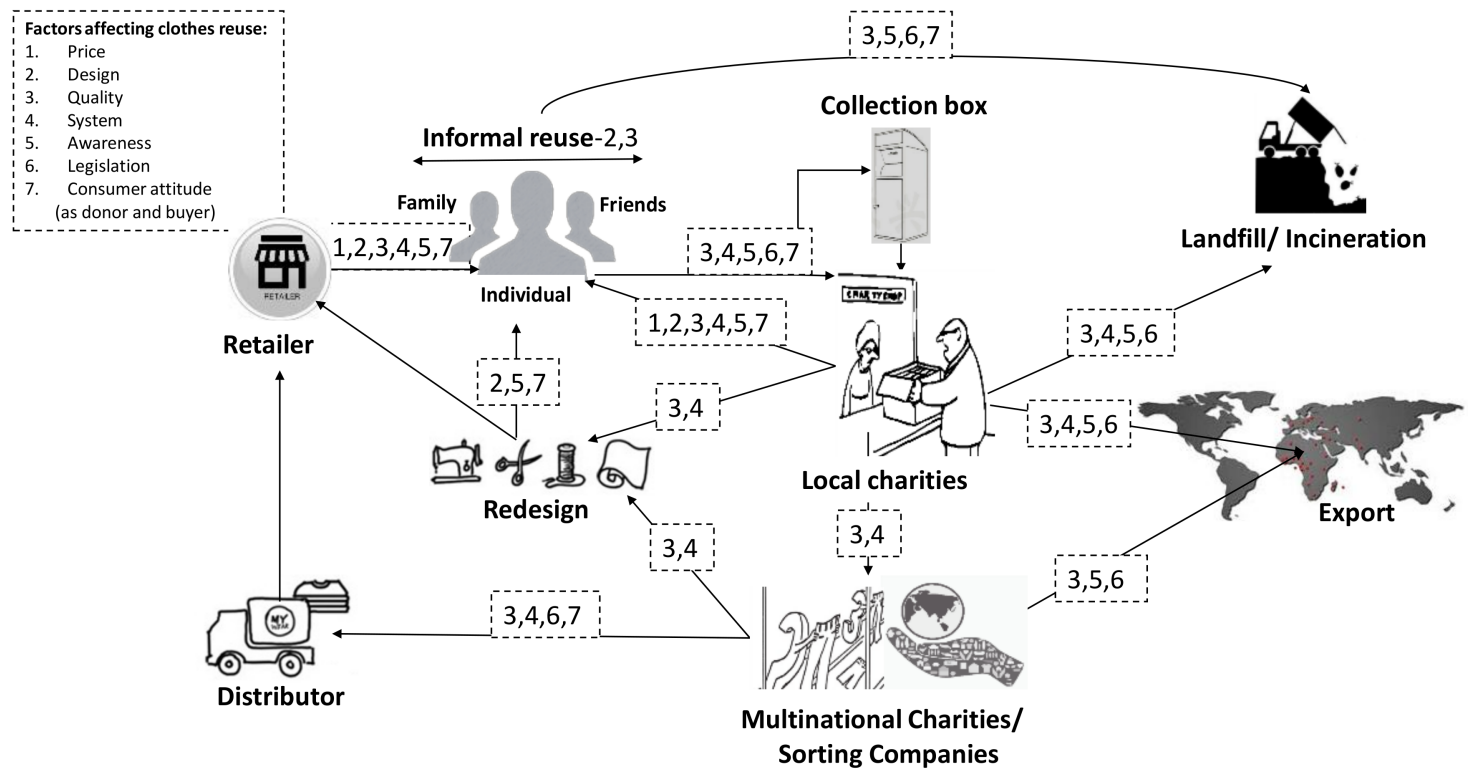

Figure 2. Model of the reuse-based clothing value chain.

The business systems have a positive impact on the RL of clothing $[29,30]$. This phenomenon is clearly visible in practice. Organizations A and B have transportation facilities for inbound logistics that enhance their collection capacity. Organization B has its own outbound logistics which helps to monthly deliver sorted clothes. However, Organization A could not deliver clothes successfully because of the lack of transportation facilities. This leads to a management problem for the sorted clothes. Organization E does not have its own collection and transportation system. However, they are able to get $800-1000 \mathrm{~kg}$ of clothes weekly for sorting. They get the help of their business partners. Charity organizations $C$ and $D$, which work under an international society, face a problem due to the unavailability of logistics facilities. Organization E has better sorting criteria, which make their sorting processes more effective as compared to other organisations. Organization B does not have set rules to sort and grade clothes. Better reprocessing facilities compared to other organisations were observed at organization $\mathrm{E}$, while organization $\mathrm{A}$ and $\mathrm{D}$ do not have any kind of reprocessing facilities. In the absence of facilities to clean and repair, even potential usable clothes are dumped for recycling and incineration [33]. The available area was found to be another important component of the business. In the current situation, organizations $C$ and $D$ reported the problem of insufficient space. Organization A is planning to move into a bigger space. Beside this, the management of organisation $D$ was found to be less enthusiastic about this business, which leads to poor functioning even though it $\mathrm{D}$ is located in a prime location. Organization $C$ is located in a small town but makes a comparatively better profit due to the excellent leadership provided by the chairman. This clearly shows the importance of different business system components. On the basis of the findings from the case studies and the above discussion, the proposition below can be formulated:

P1: The business system, which consists of a business plan, infrastructure facilities, logistics facilities, and collaboration strategies, plays an important role in the success of the reuse-based clothing value chain.

The second life of discarded clothes is largely dependent upon its quality and styles [80]. Style, construction, and fabrics play a crucial role, as observed in organization B. Consumers from nearby locations usually visit smaller charities organizations in search of vintage, even though organization $\mathrm{B}$ and $\mathrm{A}$ are not located in prime locations. The buyer of second-hand clothes always searches for better quality and design products at a lower price [81]. Organization E also mentioned that design, brand, and price matter collectively. The consumer first looks at the design, then at the quality/brand, and finally at the price to make a purchase decision. Organization D also highlighted that the price of 
a product matters a lot. Organization A and B are not located in prime locations, so they sell clothes at a lower price that attracts customers from nearby areas. The founder of organization B stated that they face tough competition from other second-hand stores. This is largely due to the entry of various professional and for-profit organizations in the second-hand clothing business [21]. The product of famous clothes brands is considered as diamond and is always handpicked by local buyers and international traders. Hence, the following proposition can be formulated:

P2: The design, quality, and price of a product, which depend upon the brand, construction, and material durability, are collectively deciding the success of the reuse-based clothing value chain.

Unavailability of information across all partners in the reverse supply chain is a common problem [52]. The availability of information or awareness about the used clothing business is very important for charities and consumers. Consumers are unaware of the way to minimise the environmental impact of the textile waste [54]. This is quite easily observed in the case of organization E, even though this organization has good support from the government and collaborates with a multinational charity for clothes collection. Still, the residents are unaware of its existence. There is hardly any advertisement done by this organisation to create promotion and awareness. Organization A is using almost all sorts of ways to advertise its business. Also, it collects feedback from customers to improve it. Organization B employs news coverage, while $C$ tries to invite different groups of people. The presence in the web world and on social media is also a prime focus for almost all organizations. The significance of information can be easily extracted from this discussion in the form of the proposition below:

P3: Information and awareness about reverse logistic is important for customers and organizations for the success of the reuse-based clothing value chain.

There is a need for government regulations and policies to achieve economical sustainability in the non-profit RL business [51]. Government legislation is found to have a positive influence on the RL of clothing. Till now, there are no exclusive laws framed by the government in favour of second-hand clothing. However, there are existing regulations by local municipal organisations, job agencies, and social welfare organisation, which help the charity organizations to perform the business of second-hand clothing. Municipal organisations pay the charity organisations for providing employment to the disabled, alcoholic, and prisoner persons. Similarly, job agencies contribute the $80 \%$ of the salaries of unskilled and untrained persons. Besides this, sometimes, social welfare organisations, international charity organisations, and the European Union also pay to start and run the not-for-profit businesses of second-hand clothes. Organization B gets good promotional support from Latvia government, even though it does not receive financial help. This clearly emphasises the positive impact of indirect government legislation and can be summarised into a proposition as follows:

P4: Social welfare schemes of municipalities and other government departments (in the absence of an exclusive legislation to promote clothes reuse) are important for the success of the reuse-based clothing value chain.

The consumer attitude as a donor and buyer influences the donations and sales of second-hand clothes. A study evaluating the RL has found that environmentally conscious people have a positive attitude towards conserving resources for future generations [3]. Purchase decisions about second-hand products are directly influenced by consumers' positive attitudes towards the environment and nature. An environment-conscious buyer is likely to buy more second-hand clothes. Similarly, a nature lover donor tries to discard clothes in textile banks or other textile channels. In most of the cases, donors are donating clean and wearable clothes. In bigger cities, sometimes, garbage is found in the clothes collection bins, but charity organisations located in the countryside and towns have never found this. In the current case, enough evidence was not found to achieve satisfying theoretical knowledge about consumers' attitude toward the clothes reuse practice. This is the main limitation of the current research, as data were not collected from the consumer. This could be seen as a potential subject for future research. 


\section{Conclusions}

This study has focused on the reverse logistics activities of clothing. The main activities examined in the study were collection, sorting, and reuse. This case study has provided several qualitative insights in relation to business system, awareness, legislation, and product (design, quality, and price). The findings indicated that the availability of collection bins and inbound logistics led to a better collection process. Moreover, awareness and proper information of the donors about clothes collection opportunities can be used to strengthen the process. Further, there is a need for a government-driven collection system for clothes. The sorting process need to have standardized criteria and parameters. A better warehouse and material storage layout may further help to improve the efficiency of sorting. A larger space will also help the material management of sorted and unsorted products/bales. The material management can be further improved in the presence of outbound logistics that help the movement of the sorted products. The availability of reprocessing facilities reduces the garbage volume. In the presence of repairing and cleaning facilities, a larger amount of used clothes can be routed to the reuse cycle. Clothes redesign can be considered as a way to enhance the value, i.e., aesthetic and functional value, of clothes. From a managerial perspective, investigating different factors influencing the RL of clothing provide useful insights to practitioners. The proposed model for reuse-based clothing can be considered at the time of starting a second-hand clothing business to control and monitor different factors. Researchers in the future can further study the influence of consumers' attitude on the value chain from a consumer perspective. The validation of the proposed model in different contexts can be a lucrative future research idea to enrich the existing literature on this topic.

Acknowledgments: Authors acknowledge the financial support provided by "Erasmus Mundus joint doctoral programme (SMDTex)" which is funded by the European Commission and the EU window of Chinese scholarship council. This work was also supported by the National Natural Science Foundation of China (Grant No. 61702352) and the Engineering Research Center of Clothing of Zhejiang Province (Open Research Foundation Grant No. 2018FZKF01).

Author Contributions: Manoj Kumar Paras, Daniel Ekwall, and Rudrajeet Pal conceived and designed the exploratory case study; Manoj kumar Paras collected and analyzed the data; Daniel Ekwall, Rudrajeet Pal, Antonela Curteza, Yan Chen, and Lichuan Wang contributed to fine-tune the analysis and discussion; Manoj Kumar Paras, Rudrajeet Pal, and Lichuan Wang wrote the paper.

Conflicts of Interest: The authors declare no conflict of interest. The funding sponsors had no role in the design of the study; in the collection, analyses, or interpretation of data; in the writing of the manuscript, or in the decision to publish the results.

\section{References}

1. Jayaraman, V.; Luo, Y. Creating competitive advantages through new value creation: A reverse logistics perspective. Acad. Manag. Perspect. 2007, 21, 56-73. [CrossRef]

2. Bernon, M.; Rossi, S.; Cullen, J. Retail reverse logistics: A call and grounding framework for research. Int. J. Phys. Distrib. Logist. Manag. 2011, 41, 484-510. [CrossRef]

3. Bell, J.E.; Mollenkopf, D.A.; Stolze, H.J. Natural resource scarcity and the closed-loop supply chain: A resource-advantage view. Int. J. Phys. Distrib. Logist. Manag. 2013, 43, 351-379. [CrossRef]

4. Dururu, J.; Anderson, C.; Bates, M.; Montasser, W.; Tudor, T. Enhancing engagement with community sector organisations working in sustainable waste management: A case study. Waste Manag. Res. 2015, 33, 284-290. [CrossRef] [PubMed]

5. Ruiz-Torres, A.J.; Ablanedo-Rosas, J.H.; Mukhopadhyay, S. Supplier allocation model for textile recycling operations. Int. J. Logist. Syst. Manag. 2013, 15, 108-124. [CrossRef]

6. Laitala, K.; Klepp, I.G. Consumers' Clothing Reuse: P otential in Informal Exchange. J. Consum. Policy 2014, 38, 444-457. [CrossRef]

7. Hawley, J.M. Digging for Diamonds: A Conceptual Framework for Understanding Reclaimed Textile Products. Cloth. Text. Res. J. 2006, 24, 262-275. [CrossRef] 
8. Oh, J.; Jeong, B. Profit Analysis and Supply Chain Planning Model for Closed-Loop Supply Chain in Fashion Industry. Sustainability 2014, 6, 9027-9056. [CrossRef]

9. Rogers, D.S.; Tibben-Lembke, R. An examination of reverse logistics practices. J. Bus. Logist. 2001, 22, 129-148. [CrossRef]

10. Cojocariu, C.R. The Reverse Gear of Logistics. Rev. Manag. Comp. Int. 2013, 14, 153-164.

11. Fleischmann, M.; Bloemhof-Ruwaard, J.M.; Beullens, P.; Dekker, R. Reverse logistics network design. In Reverse Logistics; Springer: Berlin/Heidelberg, Germany, 2004; pp. 65-94.

12. Bruce, M.; Daly, L.; Towers, N. Lean or agile: A solution for supply chain management in the textiles and clothing industry? Int. J. Oper. Prod. Manag. 2004, 24, 151-170. [CrossRef]

13. Svensson, G. Aspects of sustainable supply chain management (SSCM): Conceptual framework and empirical example. Supply Chain Manag. 2007, 12, 262-266. [CrossRef]

14. Tibben-Lembke, R.S.; Rogers, D.S. Differences between forward and reverse logistics in a retail environment. Supply Chain Manag. 2002, 7, 271-282. [CrossRef]

15. Abraham, N. The apparel aftermarket in India-A case study focusing on reverse logistics. J. Fash. Mark. Manag. 2011, 15, 211-227. [CrossRef]

16. Dervojeda, K.; Verzijl, D.; Rouwmaat, E. EU-circular-supply-chains. Bus. Innov. Obs. EU. 2014. Available online: https:/ / ec.europa.eu/DocsRoom/documents/13396/attachments/3/translations (accessed on 8 March 2017).

17. Morley, N.J.; Bartlett, C.; McGill, I. Maximising Reuse and Recycling of UK Clothing and Textiles A Research Report Completed for the Department for Environment, Food and October 2009; Oakdene Hollins: Aylesbury, UK, 2009; p. 10.

18. Palm, D.; Elander, M.; Watson, D.; Kiørboe, N.; Salmenperä, H.; Dahlbo, H.; Moliis, K.; Lyng, K.-A.; Valente, C.; Gíslason, S. Towards a Nordic Textile Strategy: Collection, Sorting, Reuse and Recycling of Textiles; Nordic Council of Ministers: Copenhagen, Denmark, 2014.

19. Gregson, N.; Beale, V. Wardrobe matter: The sorting, displacement and circulation of women's clothing. Geoforum 2004, 35, 689-700. [CrossRef]

20. Palm, D.; Elander, M.; Watson, D.; Kiørboe, N.; Salmenperä, H.; Dahlbo, H.; Rubach, S.; Hanssen, O.-J.; Gíslason, S.; Ingulfsvann, A.-S. A Nordic Textile Strategy: Part II: A Proposal for Increased Collection, Sorting, Reuse and Recycling of Textiles; Nordic Council of Ministers: Copenhagen, Denmark, 2015.

21. Hvass, K.K. Weaving a Path from Waste to Value: Exploring Fashion Industry Business Models and the Circular Economy. Ph.D. Thesis, Copenhagen Business School, Frederiksberg, Denmark, 2016.

22. Farrant, L.; Olsen, S.I.; Wangel, A. Environmental benefits from reusing clothes. Int. J. Life Cycle Assess. 2010, 15, 726-736. [CrossRef]

23. Hu, Z.-H.; Li, Q.; Chen, X.-J.; Wang, Y.-F. Sustainable Rent-Based Closed-Loop Supply Chain for Fashion Products. Sustainability 2014, 6, 7063-7088. [CrossRef]

24. Woolridge, A.C.; Ward, G.D.; Phillips, P.S.; Collins, M.; Gandy, S. Life cycle assessment for reuse/recycling of donated waste textiles compared to use of virgin material: An UK energy saving perspective. Resour. Conserv. Recycl. 2006, 46, 94-103. [CrossRef]

25. Paras, M.K.; Pal, R.; Ekwall, D. Systematic literature review to develop a conceptual framework for a reuse-based clothing value chain. Int. Rev. Retail Distrib. Consum. Res. 2017, 1-28. [CrossRef]

26. Allerston, P. Reconstructing the second-hand clothes trade in sixteenth- and seventeenth-century Venice. Costume 1999, 33, 46-56. [CrossRef]

27. Isla, V.L. Investigating second-hand fashion trade and consumption in the Philippines: Expanding existing discourses. J. Consum. Cult. 2013, 13, 221-240. [CrossRef]

28. Norris, L. Trade and transformations of secondhand clothing: Introduction. Textile 2012, 10, 128-143. [CrossRef]

29. Horne, S. Charity shops in the UK. Int. J. Retail Distrib. Manag. 1998, 26, 155-161. [CrossRef]

30. Tipper, M.J.; Drivas, I.; Russell, S.J.; Ward, G.D.; Morley, N. Principles of the recovery and reuse of corporate clothing. Proc. ICE Waste Resour. Manag. 2010, 163, 165-172.

31. Parsons, E. Charity retail: Past, present and future. Int. J. Retail Distrib. Manag. 2002, 30, 586-594. [CrossRef]

32. Shen, B. Fashion Supply Chain: Lessons from H\&M. Sustainability 2014, 6, 6236-6249.

33. Botticello, J. Between classification, objectification, and perception: Processing secondhand clothing for recycling and reuse. Textile 2012, 10, 164-183. [CrossRef] 
34. Alkazam. Textile Science \& Engineering Automated Sorting Technology from T4T Can Help Improve Recovery and Efficiency. J. Text. Sci. Eng. 2013, 3, 3-5.

35. Cervellon, M.C.; Carey, L.; Harms, T. Something old, something used: Determinants of women's purchase of vintage fashion vs second-hand fashion. Int. J. Retail Distrib. Manag. 2012, 40, 956-974. [CrossRef]

36. DeLong, M.; Heinemann, B.; Reiley, K. Hooked on vintage! Fash. Theory J. Dress Body Cult. 2005, 9, $23-42$. [CrossRef]

37. Bianchi, C.; Birtwistle, G. Sell, give away, or donate: An exploratory study of fashion clothing disposal behaviour in two countries. Int. Rev. Retail Distrib. Consum. Res. 2010, 20, 353-368. [CrossRef]

38. Ekstrom, K.M.; Salomonson, N. Reuse and Recycling of Clothing and Textiles-A Network Approach. J. Macromark. 2014, 34, 383-399. [CrossRef]

39. Pal, R. Sustainable Business Development through Designing Approaches for Fashion Value Chains. In Roadmap to Sustainable Textiles and Clothing: Environmental and Social Aspects of Textiles and Clothing Supply Chain; Springer Science + Business Media: Singapore, 2014; pp. 227-261.

40. Morana, R.; Seuring, S. End-of-life returns of long-lived products from end customer- insights from an ideally set up closed-loop supply chain. Int. J. Prod. Res. 2007, 45, 4423-4437. [CrossRef]

41. Fernandez, N.P. Innovations for home dressmaking and the popularization of stylish dress. J. Am. Cult. 1994, 17, 23-33. [CrossRef]

42. Sanderson, E.C. Nearly new: The second-hand clothing trade in eighteenth-century Edinburgh. Costume 1997, 31, 38-48. [CrossRef]

43. Lemire, B. The secondhand clothing trade in Europe and beyond: Stages of development and enterprise in a changing material world, C. 1600-1850. Textile 2012, 10, 144-163. [CrossRef]

44. Guiot, D.; Roux, D. A second-hand shoppers' motivation scale: Antecedents, consequences, and implications for retailers. J. Retail. 2010, 86, 383-399. [CrossRef]

45. Toyasaki, F.; Wakolbinger, T.; Kettinger, W.J. The value of information systems for product recovery management. Int. J. Prod. Res. 2013, 51, 1214-1235. [CrossRef]

46. Horvath, P.A.; Autry, C.W.; Wilcox, W.E. Liquidity implications of reverse logistics for retailers: A Markov chain approach. J. Retail. 2005, 81, 191-203. [CrossRef]

47. Vorasayan, J.; Ryan, S.M. Optimal price and quantity of refurbished products. Prod. Oper. Manag. 2006, 15, 369-383. [CrossRef]

48. Cruz-Rivera, R.; Ertel, J. Reverse logistics network design for the collection of End-of-Life Vehicles in Mexico. Eur. J. Oper. Res. 2009, 196, 930-939. [CrossRef]

49. Zhao, J.; Liu, W.; Wei, J. Pricing and Remanufacturing Decisions of a Decentralized Fuzzy Supply Chain. Discret. Dyn. Nat. Soc. 2013, 2013, 986704. [CrossRef]

50. Atasu, A.; Guide, V.D.R., Jr.; Van Wassenhove, L.N. Product reuse economics in closed-loop supply chain research. Prod. Oper. Manag. 2008, 17, 483-496. [CrossRef]

51. Das, D.; Dutta, P. Design and analysis of a closed-loop supply chain in presence of promotional offer. Int. J. Prod. Res. 2015, 53, 141-165. [CrossRef]

52. Ketzenberg, M. The value of information in a capacitated closed loop supply chain. Eur. J. Oper. Res. 2009, 198, 491-503. [CrossRef]

53. Abimbola, $\mathrm{O}$. The international trade in secondhand clothing: Managing information asymmetry between west African and British traders. Textile 2012, 10, 184-199. [CrossRef]

54. Morgan, L.R.; Birtwistle, G. An investigation of young fashion consumers' disposal habits. Int. J. Consum. Stud. 2009, 33, 190-198. [CrossRef]

55. Li, S.; Shi, L.; Feng, X.; Li, K. Reverse channel design: The impacts of differential pricing and extended producer responsibility. Int. J. Shipp. Transp. Logist. 2012, 4, 357-375. [CrossRef]

56. Ma, W.-M.; Zhao, Z.; Ke, H. Dual-channel closed-loop supply chain with government consumption-subsidy. Eur. J. Oper. Res. 2013, 226, 221-227. [CrossRef]

57. Lee, J.-E.; Lee, K.-D. Integrated forward and reverse logistics model: A case study in distilling and sale company in Korea. Int. J. Innov. Comput. Inf. Control 2012, 8, 4483-4495.

58. Lim, W.M.; Ting, D.H.; Wong, W.Y.; Khoo, P.T. Apparel acquisition: Why more is less? Manag. Mark. 2012, 7, 437-448.

59. Bianchi, C.; Birtwistle, G. Consumer clothing disposal behaviour: A comparative study. Int. J. Consum. Stud. 2012, 36, 335-341. [CrossRef] 
60. Hiller Connell, K.Y. Exploring consumers' perceptions of eco-conscious apparel acquisition behaviors. Soc. Responsib. J. 2011, 7, 61-73. [CrossRef]

61. Goworek, H. Social and environmental sustainability in the clothing industry: A case study of a fair trade retailer. Soc. Responsib. J. 2011, 7, 74-86. [CrossRef]

62. Wang, Y.; Wiegerinck, V.; Krikke, H.; Zhang, H. Understanding the purchase intention towards remanufactured product in closed-loop supply chains An empirical study in China. Int. J. Phys. Distrib. Logist. Manag. 2013, 43, 866-888. [CrossRef]

63. Norum, P.S. Examination of Apparel Maintenance Skills and Practices: Implications for Sustainable Clothing Consumption. Fam. Consum. Sci. Res. J. 2013, 42, 124-137. [CrossRef]

64. Paras, M.K.; Curteza, A. Revisiting upcycling phenomena: A concept in clothing industry. Res. J. Text. Appar. 2018, 22, 46-58. [CrossRef]

65. Hernadi, P. Literary interpretation and the rhetoric of the human sciences. In The Rhetoric of the Human Sciences; The University of Wisconsin Press: Madison, WI, USA, 1987.

66. Glaser, B.G.; Strauss, A.L. The Discovery of Grounded Theory: Strategies for Qualitative Research; Routledge: Piscataway, NJ, USA, 1967.

67. Czarniawska, B. Narrating the Organization: Dramas of Institutional Identity; University of Chicago Press: Chicago, IL, USA, 1997.

68. Herriott, R.E.; Firestone, W.A. Multisite Qualitative Policy Research: Optimizing Description and Generalizability. Educ. Res. 1983, 12, 14-19. [CrossRef]

69. Ellram, L.M. The use of the case study method in logistics research. J. Bus. Logist. 1996, 17, 127-132.

70. Czarniawska, B. Social Science Research: From Field to Desk; SAGE Publications: Thousand Oaks, CA, USA, 2014.

71. Kvale, S. InterViews: An Introduction to Qualitative Research Writing; Sage Publications: Thousand Oaks, CA, USA, 1996.

72. Charmaz, K. Constructing Grounded Theory: A Practical Guide through Qualitative Research; Sage Publications Ltd.: London, UK, 2006.

73. Silverman, D. Interpreting Qualitative Data; Sage: Newcastle upon Tyne, UK, 2015.

74. Brinkmann, S. Qualitative Inquiry in Everyday Life: Working with Everyday Life Materials; SAGE Publications Ltd.: Thousand Oaks, CA, USA, 2012.

75. Collier, J.; Collier, M. Visual Anthropology: Photography as a Research Method; UNM Press: Albuquerque, NM, USA, 1986.

76. Zimmerman, D.H.; Wieder, D.L. The Diary: Diary-Interview Method. J. Contemp. Ethnogr. 1977, 5, 479-498. [CrossRef]

77. Propp, V. Morphology of the Folktale, 2nd ed.; University of Texas Press: Austin, TX, USA, 1968.

78. Greimas, A.J.; Courtés, J.; Crist, L.; Patte, D. Semiotics and Language: An Analytical Dictionary; Cambridge University Press: Cambridge, UK, 1982.

79. Paras, M.K.; Pal, R. Application of Markov chain for LCA: A study on the clothes 'reuse' in Nordic countries. Int. J. Adv. Manuf. Technol. 2018, 94, 191-201. [CrossRef]

80. Norris, L. Tracking Globalization: Recycling Indian Clothing: Global Contexts of Reuse and Value; Indiana University Press: Bloomington, IN, USA, 2014.

81. Lehr, C.B.; Thun, J.-H.; Milling, P.M. From waste to value-A system dynamics model for strategic decision-making in closed-loop supply chains. Int. J. Prod. Res. 2013, 51, 4105-4116. [CrossRef]

(C) 2018 by the authors. Licensee MDPI, Basel, Switzerland. This article is an open access article distributed under the terms and conditions of the Creative Commons Attribution (CC BY) license (http://creativecommons.org/licenses/by/4.0/). 